\title{
STRATEGI GERAKAN KELOMPOK KEPENTINGAN DALAM PENGAWASAN PENGENDALIAN PEMANFAATAN RUANG KAWASAN BANDUNG UTARA
}

\author{
Novie Indrawati Sagita \\ Departemen Ilmu Pemerintahan Universitas Padjadjaran \\ E-mail: novindsa@gmail.com
}

\begin{abstract}
ABSTRAK
Kawasan Bandung Utara (KBU) ditetapkan sebagai kawasan konservasi untuk melindungi lingkungan alam untuk kegiatan kehidupan dan pembangunan kota di wilayah sekitarnya. KBU menjadi magnet para pemilik modal untuk berinvestasi di wilayah ini untuk membangun perumahan dan fasilitas pariwisata. Pembangunan di KBU telah memperoleh perlawanan dari kelompok-kelompok kepentingan yang dianggap telah menyebabkan kerusakan lingkungan dan dampak sosial-ekonomi bagi masyarakat sekitar. Pembangunan di KBU jelas melanggar peraturan daerah Nomor 1 tahun 2008, di mana setiap izin mendirikan bangunan (IMB) yang dikeluarkan oleh kabupaten / kota harus memiliki rekomendasi dari gubernur, tetapi penyimpangan perizinan sebagai kolusi pejabat pemerintah dan pemilik modal terus berlanjut. Metode penelitian ini menggunakan pendekatan kualitatif deskriptif, yang menggambarkan dan menganalisis penyimpangan perizinan dalam pembangunan KBU. Hasil penelitian menunjukkan bahwa strategi kelompok kepentingan belum efektif dalam menekan pemerintah untuk menghentikan pemberian izin dan mencegah pembangunan di KBU. Gerakan kelompok kepentingan harus memenangkan dukungan melalui pembentukan opini dengan cara membangun kesadaran masyarakat tentang dampak kerusakan lingkungan akibat pembangunan di KBU. pembentukan opini dianggap lebih efektif bila upaya ini didukung oleh bantuan media massa dalam menyebarluaskan pendapat.
\end{abstract}

Kata kunci: kelompok kepentingan, Kawasan Bandung Utara, degradasi lingkungan.

\section{THE STRATEGY OF INTEREST GROUP IN SUPERVISORY CONTROL OF SPATIAL USE IN NORTH BANDUNG AREA}

\begin{abstract}
North Bandung area (KBU) is designated as a conservation area to protect the natural environment for the activities of life and urban development in the surrounding region. $K B U$ become a magnet of the owners of capital to invest in the region to build a residential and tourism facilities. Development in KBU have acquired resistance from interest groups as deemed to have caused environmental damage and socio-economic impact to the surrounding community. Development in KBU clearly violate local regulations No. 1 of 2008, where every building permit (IMB) issued by the district / city must have a recommendation from the governor, but the deviations of licensing as a collusion of government officials and the owners of capital continues. This research method using descriptive qualitative approach, which describes and analyzes the licensing irregularities in the construction of $K B U$. The results showed that the strategy of interest groups have not been effective in pressuring the government to stop granting licenses and prevent development in KBU. Movement of the interest groups need to be winning support through the formation of opinion in a way to build public awareness about the impact of environmental degradation as a result of development at KBU. Opinion formation is considered to be more effective when these efforts were supported by the help of the mass media in disseminating the opinion.
\end{abstract}

Keywords : interest group, Bandung North Area, environmental degradation. 


\section{PENDAHULUAN}

Kawasan Bandung Utara selanjutnya disingkat KBU, merupakan kawasan perbukitan yang berada dalam wilayah adminisitratif 4 (empat) kabupaten/kota, yaitu Kabupaten Bandung, Kabupaten Bandung Barat, Kota Bandung dan Kota Cimahi. Sejak jaman kolonial, KBU sudah ditetapkan sebagai kawasan konservasi yang bertujuan memberikan perlindungan lingkungan alam bagi aktivitas kehidupan dan perkembangan kota metropolitan (Bandung Raya) yang berada di bawahnya.

KBU ditetapkan sebagai Kawasan Strategis Provinsi (KSP) dalam RTRW Provinsi Jawa Barat 2009-2029. KBU berfungsi sebagai daerah resapan air yang menyuplai sedikitnya $60 \%$ kebutuhan air daerah sekitarnya, dan juga berpotensi menimbulkan masalah lingkungan. Berdasarkan fungsi konservasi dan potensi kebencanaan lingkungan yang dampaknya bersifat lintas kabupaten/kota, maka Pemerintah Provinsi Jawa Barat berkomitmen untuk mengatur perencanaan dan pemanfaatan KBU ini. Adapun arah kebijakan Pemerintah Provinsi dalam penanganan kawasan ini adalah dengan melakukan rehabilitasi dan revitalisasi fungsi konservasi kawasan serta pembatasan dan pengendalian pembangunan di kawasan tersebut.

Dalam rangka pengendalian pemanfaatan ruang KBU maka Pemerintah Provinsi Jawa Barat berinisiatif mengeluarkan regulasi untuk menertibkan pembangunan yang ada di kawasan tersebut. Regulasi terbaru terkait Pengendalian Kawasan Bandung Utara diatur dalam Perda Provinsi Jawa Barat Nomor 1 Tahun 2008 tentang Pengendalian Pemanfaatan Kawasan Bandung Utara dan Peraturan Gubernur Nomor 58 Tahun 2011 tentang Pedoman Teknis Pelaksanaan Perda Nomor 1 Tahun 2008. Berdasarkan Perda Nomor 1 Tahun 2008, kedudukan perda ini antara lain untuk pengaturan pemanfaatan ruang di KBU dan menjadi dasar penetapan perijinan pemanfaatan ruang di KBU. Dalam pengaturan kewenangan masih menurut Perda Nomor 1 Tahun 2008, disebutkan bahwa ijin pemanfaatan ruang di KBU diterbitkan oleh bupati/walikota yang mana sebelum bupati/walikota menerbitkan izin pemanfaatan ruang KBU perlu mendapat rekomendasi dari gubernur.
Namun demikian, penerbitan perda tersebut tidak menyurutkan proses kegiatan pembangunan di kawasan KBU. Bangunan liar masih banyak berdiri tanpa ijin dari pemerintah daerah setempat, baik bangunan untuk perusahaan dan apartemen. Meskipun pemerintah sudah menegur pemilik bangunan untuk memenuhi mekanisme perijinan, pem-bangunan pun tetap berlanjut. Terdapat dua masalah yang terjadi di wilayah KBU, yaitu bangunan yang berdiri di lahan negara dan bangunan yang berdiri di lahan milik pribadi, yang mana pelaksanaan pembangunan keduanya melanggar ketentuan pemanfaatan ruang yang telah ditetapkan juga bangunan yang melanggar prosedur perijinan ${ }^{1}$. Banyak bangunan di KBU yang berdiri tanpa memiliki IMB dan tidak mengantongi rekomendasi gubernur. Namun tidak sedikit pula bangunan yang berdiri meskipun memiliki IMB, namun tidak mengantongi rekomendasi gubernur.

Berbagai regulasi sudah diterbitkan Provinsi dalam rangka mengendalikan dan menata pemanfaatan ruang di KBU, namun regulasi tersebut tidak memiliki efek perubahan sama sekali. Kerusakan lahan KBU akibat pembangunan semakin parah hingga sekarang, yang mengakibatkan $75 \%$ lahan KBU yang memiliki luasan 38.543 hektare tersebut dalam kondisi kritis. Walhi Jabar memperkirakan sekitar 3.000 bangunan komersil di Kawasan Bandung Utara, dan diperkirakan sekitar 30 bangunan \% bermasalah dari aspek perizinan tata ruang dan lingkungan hidup ${ }^{2}$.

Dengan adanya pelanggaran aspek perizinan dalam pemanfaatan ruang di KBU, banyak organisasi masyarakat yang memiliki kepentingan dan kepedulian menjaga kelestarian lingkungan di KBU turun ke jalan dan menyampaikan protes kepada pemerintah Provinsi Jawa Barat maupun kabupaten/kota atas lemahnya pengawasan dan penyimpangan perijinan beberapa bangunan komersil yang berdiri di KBU.

\section{METODE}

MetodePenelitian inimenggunakan pendekatan kualitatif deskriptif, yakni suatu metode

\footnotetext{
${ }^{1}$ Pernyataan Wakil Gubernur Jawa Barat, pada https://m.tempo. co/read/news/2014/08/20/058601022/penertiban-bangunan-liar-dibandung-utara-mandek, diakses tanggal 16 Juli 2015

${ }^{2}$ Audit Bangunan di Kawasan Bandung Utara, Suara pembaharuan, 9 Desember 2013
} 
penelitian yang berupaya menggambarkan, menganalisis dan mengintepretasikan gejala sosial yang terjadi sehingga memperoleh suatu gambaran yang utuh dari suatu peristiwa atau realita sosial. Penelitian inimenggunakan 2 (dua) jenis data yaitu data primer dan data sekunder. Data primer merupakan data yang diperoleh langsung dari lapangan penelitian melalui pengamatan dan wawancara. Sedangkan data sekunder diperoleh dari dokumen-dokumen/arsip organisasidan pemberitaan dimedia massa. Hasil pengumpulan data dianalisis melalui beberapa tahapan yakni tahap kategorisasi berdasarkan jenis data, menyeleksi dan mereduksi data sesuai dengan masalah penelitian, kemudian melakukan intepretasi data dan diakhiri dengan penarikan kesimpulan.

\section{TINJAUAN TEORI}

Kelompok kepentingan memiliki pengertian sebagai organisasi yang dibentuk oleh sejumlah orang karena adanya kesamaan sikap, kepercayaan, dan/atau tujuan. Kelompok kepentingan pada dasarnya asosiasi manusia yang terorganisir, memiliki keanggotaan, pola kepemimpinan, sumber keuangan untuk membiayai kegiatan, dan pola komunikasi ke dalam maupun ke luar organisasi. Dalam sistem politik, sebagaimana teori struktural fungsional yang dikemukakanoleh GabrielA.Almond, kelompok kepentingan memiliki fungsi artikulasi, yakni memperkuat dan mengefektifkan penyampaian aspirasi/tuntutan-tuntutan masyarakat, sehingga dapat mem-pengaruhi kebijakan pemerintah. Selain fungsi artikulasi, kelompok kepentingan juga men-jalankan fungsi pengawasan dan melakukan kritik terhadap kinerja pemerintah (Surbakti, 1992: 109).

Terdapat 4 (empat) jenis kelompok kepentingan dalam mempengaruhi kehidupan sosial politik, yaitu :

a. Kelompok anomik, yakni kelompok kepentingan yang berasal dari unsur masyarakat dan tidak memiliki nilai atau norma standar yang mengatur sebagaimana halnya dalam suatu organisasi. Gerakan politik dilakukan secara spontan dan partisipasi politik cenderung bersifat non konvensional.

b. Kelompok non assosiasional, merupakan kelompok yang tidak terorganisir dengan baik, tidak memiliki agenda kerja secara berkala, umumnya berasal dari klan keluarga yang berpengaruh, pemimpin-pemimpin agama, kelompok etnis, kelompok regional maupun lokal. Gerakan politik yang dilakukan dengan memanfaatkan hubungan pribadi dan kedekatan dengan elit politik.

c. Kelompok institusional adalah kelompok kepentingan yang bersifat formal, berbadan hukum. Anggota kelompok ini umumnya berasal dari basis profesi yang sama.

d. Kelompok assosiasional adalah kelompok kepentingan yang bersifat formal, menggunakan staf yang bekerja penuh, memiliki agenda dan prosedur kerja yang teratur dan diakui masyarakat atas kemampuannya secara efektif menyampaikan tuntutan kepada pemerintah (Almond dalam Mas'oed dan MacAndrews, 1995: 54-56)

Kelompok kepentingan memiliki 4 (empat) peranan dalam kehidupan bernegara yaitu (1) katalisasi perubahan sistem dengan cara melakukan advokasi dan berusaha membentuk kesadaran kolektif masyarakat terhadap masalah-masalah yang penting dalam kehidupan. Melalui peran ini, kelompok kepentingan berusaha mengembangkan kemauan politik dan inisiatif masyarakat sehingga dapat bersama-sama mempengaruhi kebijakan; (2) Monitoring atau melakukan pengawasan terhadap penyelenggaraan pemerintahan. Melakukan kritik hingga memprotes apabila ditemukan indikasi penyalahgunaan kekuasaan dan pelanggaran hukum oleh pejabat negara; (3) memfasilitasi rekonsiliasi warga negara dengan lembaga peradilan. Kelompok kepentingan ini kerap membela masyarakat umum yang kerap menjadi korban kekerasan dan korban ketidakadilan hukum oleh pemerintah, dan (4) mewujudkan sejumlah program dalam rangka pemberdayaan masyarakat (Gaffar, 1999: 204).

Dalam penyampaian kepentingan, kelompok kepentingan bisa jadi berubah menjadi kelompok penekan apabila upaya penyampaian tuntutan disampaikan secara intensif dengan cara melancarkan taktik-taktik dan tekanan politik yang luar biasa untuk mempengaruhi kebijakan, sehingga pemerintah maupun pejabat politik bersedia menyetujui tuntutan mereka (Duverger, 1984: 123). Ada pun taktik atau strategi gerakan yang dilakukan oleh kelompok kepentingan dalam menyampaikan tuntutannya melalui cara-cara sebagai berikut : 
a. Menyampaikan tuntutan/aspirasi kepada partai politik

b. Partisipasi dalam proses perumusan kebijakan

c. Melakukan lobby dan negosiasi kepada pejabat politik

d. Memanfaatkan hubungan pribadi dengan elit politik

e. Penyampaian kritik dan aspirasi melalui media massa

f. Gerakan non konvensional yakni bentuk partisipasi politik dengan cara melakukan kekerasan seperti melakukan demonstrasi, aksi mogok, memblokir jalan, konvoy besarbesaran dan melakukan tindak kekerasan lainnya.

Berdasarkan taktik atau strategi gerakan diatas, efektifitas pelaksanaan peran kelompok kepentingan sangat bergantung pada intensitas gerakan, dukungan masyarakat terhadap isu yang dilontarkan, kekuatan argumen dan komunikasi dalam lobby dan negosiasi, hubungan interpersonal dan seberapa besar kemampuan mengumpulkan massa yang sebanyak-banyaknya sebagai sumber kekuatan gerakan dalam melakukan tekanan sehingga memaksa pemerintah untuk mengikuti tuntutan dari kelompok kepentingan (Duverger, 1984: 135-148).

\section{HASIL DAN PEMBAHASAN}

Pelestarian lingkungan di KBU menjadi concern banyak kelompok masyarakat (kelompok kepentingan). Perlawanan kelompok masyarakat terhadap penyimpangan pemanfaatan lahan di KBU telah dilakukan sejak tahun 1994 ketika Pemerintah Provinsi Jawa Barat mulai membuka kesempatan dan memberikan ijin bagi pengusaha pengembang untuk membuka lahan dan mendirikan bangunan di Kawasan Tersebut. Meskipun regulasi daerah yang menetapkan KBU sebagai kawasan lindung atau kawasan konservasi, namun regu-lasi ini tidak memiliki kekuatan untuk mencegah perusakan lingkungan di kawasan tersebut, akibat inkonsistensi baik Pemerintah Provinsi maupun Pemerintah Kabupaten/Kota dalam merumuskan kebijakan tata ruang khususnya pemanfaatan lahan di KBU.

Banyak regulasi daerah diterbitkan dalam rangka penanganan $\mathrm{KBU}$, diantaranya jauh sebelum terbitnya Perda Provinsi Jawa Barat Nomor 1 Tahun 2008, Gubernur Jawa Barat telah mengeluarkan Surat Keputusan No. 181.1/SK.1624-Bapp/1982 yang isinya berkaitan dengan Penetapan KBU sebagai kawasan lindung atau kawasan konservasi. Berdasarkan surat keputusan tersebut, peruntukan wila yah KBU terbagi menjadi lahan hutan lindung, lahan untuk pertanian tanaman keras, dan lahan untuk pertanian non tanaman keras. Namun demikian, SK Gubernur tersebut tidak diterapkan secara konsisten, faktanya pembangunan pemukiman (mewah) di KBU terus berlangsung. Di kalangan pengusaha pengembang dan asosiasi Real Estate Indonesia (REI) mengatakan bahwa SK Gubernur 1982 tersebut tidak menutup kemungkinan adanya pembangunan di KBU, selama pembangunan dilakukan di lahan pertanian non tanaman keras $^{3}$. Pernyataan ini dikuatkan dengan adanya Instruksi Gubernur Jawa Barat masih di tahun yang sama, yakni Instruksi Gubernur Nomor 640 tahun 1982 yang isinya memperbolehkan pembangunan di KBU. Sejak dikeluarkannya surat keputusan gubernur tersebut, banyak pengembang mengajukan izin lokasi di Kawasan Bandung Utara.

Melihat kondisi maraknya pembangunan di KBU, pada tahun 1993, Gubernur Kepala Daerah Tingkat I Jawa Barat menerbitkan SK Nomor 593.82/4535-Bapp/1993yang isinya bertujuan untuk mengendalikan penggunaan lahan di Kawasan Bandung Utara terutama pembangunan perumahan. Namun sekali lagi, kebijakan ini tidak bertahan lama. Lima bulan kemudian sejak SK tahun 1993 dikeluarkan, pemerintah Provinsi Jawa Barat menerbitkan surat susulan Nomor 593.82/1174-Bapp/1994 tanggal 19 April Tahun 1994 yang isinya memberi kesempatan bagi pengembang untuk mengajukan permohonan izin membangun dan melakukan pembebasan tanah di KBU meski dengan persyaratan yang lebih ketat. Sejak SK tahun 1994 ini dikeluarkan, terdapat 29 pengembang diberikan izin lokasi untuk membangun perumahan di Kawasan Bandung Utara.

Terdapat dua kasus utama pelanggaran pembangunan sebagai dampak dari kebijakan Gubernur tahun 1982 hingga 1994, yang mem-

3 Kasus Bandung Utara Resahkan Investor dan Konsumen, Republika, Selasa 24 Januari 1995, pernyataan dikemukakan oleh Paskah Suzetta yang pada waktu itu menjabat sebagai Wakil Ketua DPD REI Jawa Barat 
berikan kesempatan dan izin kepada pengembang untuk membangun dan melakukan pembebasan tanah di KBU, yaitu dibangunnya Resor Dago Pakar di Kabupaten Bandung dan Punclut di Kota Bandung. Baik pembangunan Resor Dago Pakar dan Punclut mendapat perlawanan dari masyarakat. Pembangunan Resor Dago Pakar ditolak masyarakat karena telah menghabiskan 14 kampung dan menutup sejumlah mata air yang berada di kawasan tersebut. Sedangkan sengketa Punclut yang terjadi sejak tahun 1994, karena adanya sengketa kepemilikan tanah Punclut yang mana tanah Punclut semula diberikan kepada para veteran kemudian diambil alih oleh pemerintah dan pengelolaannya diberikan kepada swasta yakni PT. Dam Utama Sakti Prima (DUSP). Menurut masyarakat, perusahaan ini telah membabat habis hutan Punclut dan lingkungan sekitar Curug Dago untuk membangun kompleks permukiman dan resor mewah. Pembangunan kawasan Punclut tersebut ditentang oleh berbagai organisasi lingkungan hidup, karena Punclut merupakan kawasan konservasi dan berfungsi untuk melindungi Kota Bandung. Tanah Punclut adalah ex-Erpacht ${ }^{4}$ yang pada tahun 1961 sebagian telah diberikan kepada para pejuang' 45 dan pihak lain yang berjasa kepada negara berdasarkan SK Mentri Agraria No. Sk 27/Ka Tahun 1961 dalam bentuk 943 SHM (Sertifikat Hak Milik) setelah melalui proses ganti rugi kepada negara. Pada perkembangannya, para pemilik kapling tidak diperbolehkan membangun rumah di sana karena SK Gubernur Jabar tahun 1982 melarang pembangunan di KBU. Larangan membangun ini diperkuat oleh Pemerintah Provinsi Jawa Barat yang menerbitkan SK tentang status quo bagi pembangunan di KBU. Anehnya, pada tahun 1997 Menteri NegaraAgraria/Kepala BPN secara sepihak membatalkan 943 SHM tersebut dengan alasan tidak dibangun oleh pemiliknya. Pengambilalihan lahan tersebut kemudian diberikan ijin lokasi dan ijin membangun kepada PT DUSP. Atas pembatalan SHM yang diduga penuh rekayasa itu, pemindahan hak kepemilikan ini memicu konflik antara masyarakat dengan pemerintah. Di satu sisi para pejuang 45 dilarang membuat bangunan,

\footnotetext{
${ }^{4}$ Tanah Ex-Erfacht adalah tanah warisan (yang pernah dikuasai) pemerintah kolonial dan kemudian dikembalikan kepada negara
}

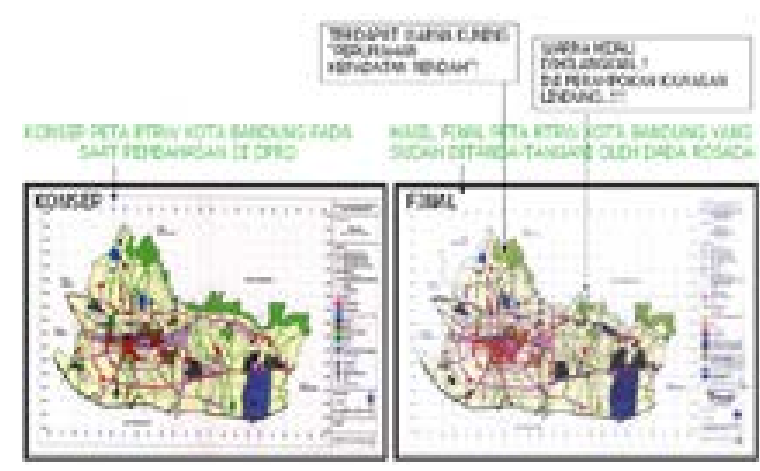

Sumber: Klipping Koalisi Masyarakat Bandung Bermartabat (KMBB),

2015

Gambar 1. Perbedaan Rancangan Peta Pada Penyusunan Perubahan Perda No. 2 Tahun 2004

namun di sisi lain mereka dipersalahkan karena tidak membangun, yang mengakibatkan sertifikat kepemilikan tanah tersebut dicabut, dan diberikan kepada perusahaan pengembang PT DUSP. Para aktivis lingkungan dan $\mathrm{LSM}^{5}$ menolak pembangunan kawasan Punclut ini karena menurut mereka ijin yang diberikan Pemerintah Kota Bandung sangat bernuansa kolusi, yang mana pemberian ijin lokasi kepada PT DUSP tersebut bertentangan dengan Perda Kota Bandung Nomor 2 tahun 2004 Tentang RTRW Kota Bandung yang menyebutkan bahwa wilayah Punclut adalah kawasan lindung atau sebagai "cacthment area."

Bukti adanya kolusi antara Pemerintah Kota Bandung dan PT DUSP, ketika pemerintah kota mengubah Perda RTRW tahun 2004 menjadi Perda Kota Bandung Nomor 3 tahun 2006, yang mana perda baru ini bertentangan dengan perundang-undangan di atasnya, di antaranya UU Nomor 26 tahun 2007 tentang Penataan Ruang, PP Nomor 47 tahun 1997 tentang Rencana Tata Ruang Wilayah Nasional, dan Perda Provinsi Jawa Barat Nomor 2 tahun 2003 tentang RTRW Provinsi Jawa Barat. Berdasarkan Perda Nomor 3 Tahun 2006 tentang Perubahan Atas Perda Kota Bandung Nomor 2 Tahun 2003, wilayah

${ }^{5}$ Gugatan pembangunan di Kawasan Punclut ini didemo oleh Gerakan Aliansi Aktivis Lingkungan Bandung ini terdiri dari :WALHI Jawa Barat, DPKLTS, FK3I Jabar, Bandung Spirit, Puragabaya, GAPELI, KONUS, Forum DPRD, LSM Abdi Bangsa, FPLH, Komunitas Seniman Bandung, Gampar, KDMB, Gerbong bawah tanah, Keluaraga PecintaPunclut, KOPPLING, VikingPersib Club, Aliansi rakyat bersatu, YPBB, Katurnagari, Balarea, KPP PTDI, Ratu lemah gemulai, Kolektiv hijau merdeka, KPJ Bandung,SPBU, SAPMA PP Jabar, Peradaban bandung timur, Mayapada, Germata, Forum rakyat Jabar untuk perubahan, GMBI, Waliwis Lembang, Napak Giri SMKN 8, Palawa Unpad, Argawilis STSI, MPKA Rimbawan Unwim, Maperpa Unwim, PAL ikopin, F-TL ITB, TiangBendera ITB, Kulawargi Jayagiri, Forum Urang Sunda, POKUS, dan PASS (Penyelamat Aset Sumber daya alam dan Sumber daya manusia). 
Punclut digolongkan kawasan lindung namun peta rencana kawasan lindung telah diubah yang semula hijau (kawasan lindung), menjadi kuning yakni untuk perumahan dengan kepadatan rendah. Skenario rancangan perubahan rencana detil tata ruang di Kawasan Punclut dapat dilihat pada gambar berikut ini:

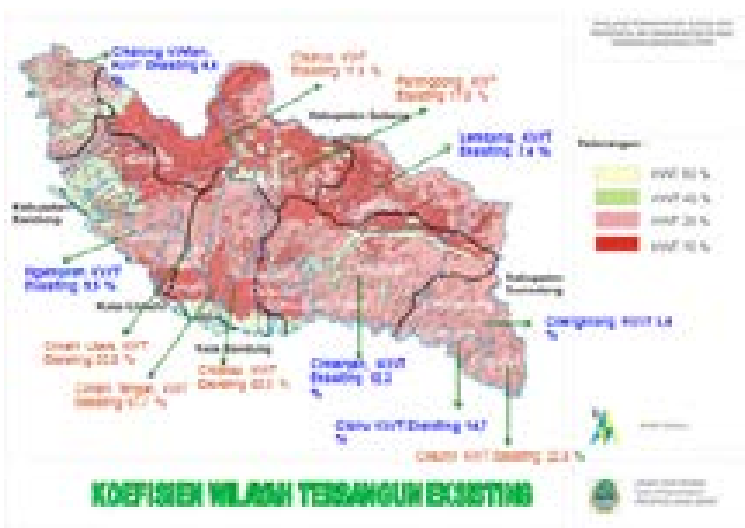

Sumber : Dinas Pemukiman dan Perumahan Provinsi Jawa Barat, 2016

\section{Gambar 2. Koefisien Wilayah Terbangun Eksisting KBU}

Akibat adanya penyimpangan pemanfaatan lahan Punclut tersebut, para aktivis peduli lingkungan, asosiasi advokat dan LSM melayangkan gugatan ke PTUN. Gugatan tersebut mengacu pada dokumen hasil pemeriksaan BPK tahun 2007. Menurut BPK, Kebijakan Walikota Menetapkan Rencana Detail Tata Ruang Kota (RDTRK) untuk Kawasan Punclut bertentangan dengan peraturan yang berlaku' Dari hasil pemeriksaan dokumen diketahui

6 Punclut adalah bagian dari KBU yang selama puluhan tahun dipertahankan sebagai Kawasan Lindung oleh kebijakan di tingkat propinsi dan nasional. Kebijakan yang telah dikeluarkan terkait penetapan Punclut adalah sebagai berikut:

- SK Gub Jabar No. 181.1/ SK.1624-Bapp/ 1982 tgl 5 November 1982 ttg Peruntukan Lahan di KBU, dimana pada lampirannya peruntukkan kawasan Punclut adalah $100 \%$ dilindungi.

- Instruksi Gubernur KDH Tk. I Jabar No. 640/ SK.1625 Bapp/ 1982 tgl 5 November 1982 ttg Pemberian Ijin Pembangunan di KBU

- Surat Gubernur KDH Tk. I Jawa Barat No. 593.82/ 1174Bapp/ 1994 tgl 19 Maret 1994 ttg Permohonan Ijin Lokasi dan Pembebasan Tanah di KBU.

- Surat Gubernur KDH Tk. I Jabar No. 593/ 1221/Bapp/ 1994 tgl 22 April 1994 ttg Pengendalian Penggunaan Lahan di KBU.

- SK Gubernur KDH Tk. I Jawa Barat No. 660/ 4244/ Bappeda/ 1994 tgl 31 Oktober 1994 ttg Pengamanan Wilayah Inti Bandung Raya Bagian Utara.

- Surat Menteri Negara Agraria/ Kepala BPN No. 470-380 tgl 7 Februari 1995 ttg Penertiban Tanah KBU

- SK Gubernur KDH Tk. I Jawa Barat No. 912.05/ SK-1845Bappeda/ 95 tgl 3 November 1995 ttg Tim Pengendali Pembangunan Wilayah Inti Bandung Raya Bagian Utara.

- SK Gub KDH Tk. I Jawa Barat No. 912/ 333-Bappeda/ 1996 tgl 31 Januari 1996 ttg Penanganan Kegiatan Pembangunan Wilayah Inti Bandung Raya Bagian Utara.

- SK Meneg LH/ Kepala Bapedal No. Kep. 35/ MenLH/ 12/ 1998 tgl 30 Desember 1998 ttg Persetujuan Amdal, RKL dan RPL Regional pembangunan KBU.

- Surat Gubernur Nomor 912/424/Bappeda tanggal 10 Februari 2005 tentang Status Quo Kawasan Punclut.

- Dokumen Pemeriksaan BPK RI. 2007. http://www.bpk.go.id/ doc/hapsem/2007ii/APBD/273_Kota_Bandung_Perc_Lingk_ udara.PDF, diakses pada tanggal 25 Januari $201 \overline{6}$ bahwa Kawasan Punclut telah dikembangkan untuk Kawasan Hunian dan Pariwisata Terpadu yang dilaksanakan oleh PT DUSP. Gugatan kelompok masyarakat ke PTUN terkait penyimpangan pembangunan di lahan Punclut hingga sekarang belum terselesaikan.

Masalah penyimpangan pemanfaatan lahan di KBU tidak hanya berakhir pada penolakan pembangunan Resor Dago dan Kawasan Punclut saja, melainkan terus berlanjut hingga sekarang. Melalui pengamatan citra satelit dan foto udara yang dilakukan oleh DPKLTS (Dewan Pemerhati Kehutanan dan Lingkungan Tatar Sunda), kerusakan Kawasan Bandung Utara hingga tahun 2003 mencapai 70\%. Jika pada tahun 1960, koefisien run-off KBU hanya 40\%, di tahun 2004 koefisien run-off KBU mencapai 90\%. Berdasarkan hasil evaluasi Dinas Pemukiman dan Perumahan Provinsi Jawa Barat Tahun 2012, Kondisi penyimpangan koefisien wilayah terbangun (KWT) di KBU

Sebagian besar berada di wilayah Kota Bandung. KBU yang berada di wilayah administratif Kota Bandung pada tahun 2012, dianggap sudah sangat padat bahkan melebihi dari batas KWT maksimal. Secara detil KWT eksisting di KBU per wilayah kecamatan kabupaten/kota dapat dilihat pada gambar di atas.

Berdasarkan gambar diatas, KBU yang memiliki koefisien wilayah terbangun (KWT) tertinggi perkecamatan adalah Kecamatan Cisarua (11,9\%) dan Kecamatan Parongpong (17,9\%), kedua kecamatan ini berada dalam wilayah administratif Kabupaten Bandung Barat. KWT KBU tertinggi di wilayah adminis-tratif Kabupaten Bandung berada di Kecamatan Cileunyi (22,6\%) dan Kecamatan Cimenyan (12,2\%). KWT KBU tertinggi di wilayah administratif Kota Cimahi adalah Kecamatan Cimahi Utara (33,8 \%) dan Cimahi Tengah (57,7\%). Sedangkan KWT KBU tertinggi di Kota Bandung adalah Kecamatan Cidadap (60,9\%). KWT tersebut menunjukkan banyaknya bangunan yang berdiri di KBU yang mengurangi porsi Ruang Terbuka Hijau, berkurangnya fungsi kawasan lindung dan resapan air yang berdampak pada kerusakan lingkungan.

Potensi alam berupa pemandangan pegunungan yang indah serta sejuknya udara di KBU bagaikan magnit yang menarik perhatian para pemilik modal untuk mengembangkan bisnis 
properti (hotel dan pemukiman mewah) dan membangun fasilitas pariwisata di KBU. Lahan KBU yang semula didominasi oleh lahan pertanian dan hutan kayu kini beralih menjadi lahan terbangun dan hutan beton. Dengan mengatasnamakan pertumbuhan ekonomi, pembangunan di KBU terus dilakukan, banyak mall, hotel, apartemen berdiri akibat lemahnya sistem kebijakan dan kekuatan modal. Para pengusaha dan pengembang berlomba-lomba membangun hotel-hotel dan apartemen baru yang megah di kawasan ini.Pembangunan di Kawasan Bandung Utara berkembang sangat pesat dan dinilai banyak yang tidak sesuai dengan peruntukkan lahan, sehingga Pemerintah Provinsi Jawa Barat menerbitkan Peraturan Daerah Nomor 1 Tahun 2008 tentang Penataan Pemanfaatan Ruang di Kawasan Bandung Utara dengan tujuan penanganan dan pengaturan pemanfaatan lahan KBU yang lebih mantap. Berdasarkan Perda Nomor 1 Tahun 2008 tersebut, setiap perijinan pembangunan (ijin lokasi dan IMB) di lokasi KBU yang diterbitkan pemerintah kabupaten/ kota perlu mendapatkan rekomendasi dari gubernur. Namun demikian, sekali lagi peraturan ini (Perda Nomor 1/2008) tidak dipatuhi dengan baik. Banyak bangunan-bangunan liar berdiri di KBU, baik bangunan yang sama sekali tidak mengantongi ijin (IMB maupun rekomendasi gubernur), dan ada juga bangunan yang memiliki IMB namun tidak mengantongi rekomendasi. Kondisi ini tentu saja bertentangan dengan peraturan pengendalian pemanfaatan ruang di KBU, Perda Nomor 1 tahun 2008.

Perlawanan kelompok masyarakat terhadap pembangunan di KBU karena dianggap tidak hanya melanggar aturan dan merusak lingkungan saja, tetapi juga berdampak pada kehidupan sosial-ekonomi masyarakat. Beberapa kasus pembangunan mendapat protes dari warga yang difasilitasi oleh organisasiorganisasi non pemerintah (LSM). Beberapa organisasi pecinta lingkungan yang banyak memberikan perhatian terhadap kelestarian lingkungan Bandung Utara dan membantu masyarakat melakukan demo penolakan diantaranya adalah Walhi, Forum Masyarakat Bangbayang-Tubagus Ismail (Formas Bagus), Forum Komunikasi Warga Ciumbuleuit Peduli Bandung (FKWCPB), Aliansi Masyarakat Bandung Utara (AMBU), Bandung Heritage,
Forum Hijau dan Dewan Pemerhati Kehutanan dan Lingkungan Tatar Sunda (DPKLTS).

Pembangunan di KBU yang paling banyak mendapat protes warga adalah pembangunan tipe high rise building (gedung-gedung tinggi seperti hotel dan apartemen). Menurut warga masyarakat dan aktivis lingkungan, pembangunan gedung-gedung tinggi hanya akan menambah kepadatan populasi penduduk, sehingga ijin pembangunan gedung-gedung tinggi tersebut harus mempertimbangkan keseimbangan daya dukung dan daya tampung lingkungan. Dengan bertambahnya populasi penduduk, diperlukan ketersediaan air yang cukup untuk memenuhi kebutuhan warga masyarakat sekitar. Sementara dengan kondisi yang ada, masyarakat seringkali mengalami kekurangan air di saat musim kemarau tiba. Dengan banyaknya pembangunan rusunami atau apartemen dapat dipastikan akan menyedot banyak air, belum lagi dengan masalah lalu lintas seiring dengan bertambahnya penduduk menuju rusunami atau apartemen tersebut akan menambah volume kendaraan yang berdampak pada kemacetan lalu lintas.

Berdasarkan keterangan dari masyarakat, masyarakat bukan tidak setuju terhadap pembangunan di KBU, namun masyarakat menghendaki pembangunan harus sesuai dengan ketentuan peraturan perundang-undangan. Pemerintah selalu mengatakan bahwa pembangunan rusunami dilakukan karena keterbatasan lahan, sehingga pemerintah memprogramkan hunian vertikal dalam rangka memenuhi kebutuhan masyarakat. Namun menurut warga, program pembangunan pemukiman vertikal tersebut sebenarnya bukan untuk memenuhi kebutuhan warga masyarakat setempat, rusunami hanyalah istilah yang dibuat agar sederhana dan dapat diterima, padahal pembangunan yang dilakukan banyak yang berwujud apartemen mewah dengan harga jual yang sangat mahal (berkisar ratusan juta hingga miliaran rupiah per unitnya). Harga yang sesungguhnya sulit dijangkau oleh masyarakat setempat. Bagi masyarakat, pembangunan perumahan mewah dan apartemen itu hanya untuk memenuhi kebutuhan masyarakat luar wilayah. Kenyataannya, beberapa apartemen yang dibangun di KBU banyak diminati oleh warga luar Bandung seperti warga Jakarta bahkan diantaranya ada yang 
dipromosikan ke Malaysia dan Singapura ${ }^{7}$.

Selain itu, keberatan masyarakat terhadap proses pembangunan di KBU terutama karena pembangunan gedung-gedung tinggi seringkali tidak melibatkan masyarakat sekitar untuk memberikan persetujuan pembangunan atau pernyataan tidak keberatan warga sebagai salah satu persyaratan proses awal pengajuan perijinan. Setiap pelaksanaan pembangunan, pengembang banyak melakukan sosialisasi kepada warga tanpa meminta persetujuan, namun daftar hadir warga dalam sosialisasi tersebut kemudian diklaim pengembang/pengelola sebagai bentuk persetujuan warga. Salah satu kecurangannya yaitu pada saat pembuatan surat keterangan tidak keberatan dari warga/tetangga, kontraktor pelaksana bangunan apartemen tersebut hanya menghubungi beberapa ketua RT dan RW, kemudian memberikan dana "kompensasi" atas pendirian bangunan Apartemen Gateway Pasteur. Tindakanini menunjukkan adanya manipulasi izin gangguan/HO (Hinder Ordonantie) atau manipulasi izin pesetujuan warga yang dilakukan oleh pengembang bersama dengan aparatur (termasuk pelibatan RT/RW) wilayah kabupaten/kota setempat.

Berikut daftar gugatan masyarakat yang dimotori oleh kelompok-kelompok kepentingan terhadap kegiatan pembangunan di KBU sejak terbitnya Perda Nomor 1 Tahun 2008. Gugatan yang berhasil dilakukan oleh kelompok kepentingan, sebagai berikut :

1. Forum Komunikasi Warga Ciumbuleuit Peduli Bandung (FKWCPB) berhasil melakukan Penolakan IMB Hotel Four R, tahun 2009, dengan alasan dampak ekologis dan sosial.

2. Formas Bagus (Forum masyarakat Bangbayang dan Tubagus Ismail) berhasil menggugat Pembangunan Rusunami Grand Dago pada tahun 2010, dengan alasan pembangunan apartemen tersebut menimbulkan dampak ekologis (kekurangan air tanah/ kesulitan air bersih dan Kemacetan) dan terciptanya konflik sosial (pertentangan antara masyarakat yang pro dan kontra)

3. Forum Hijau berhasil menggugat Pembangunan Pramestha Resort Town tahun 2013,

\footnotetext{
${ }^{7}$ Menurut pernyataan Direktur salah satu perusahaan pengembang, promosi apartemen di KBU dilakukan di Malaysia karena lesunya penjualan di dalam negeri. Tidak hanya warga Malaysia, warga Singapura pun tertarik untuk membeli apartemen di kawasan ini. Warga Malaysia dan Singapura Tertarik Apartemen Bandung, 23 September 2015, www.kompas.com diakses tanggal 4 Juni 2016
}

dengan alasan pembangunan menim-bulkan dampak ekologis dan berbatasan dengan Taman Hutan Raya.

4. Warga Desa Gudang Kahuripan, Kecamatan Lembang, Kabupaten Bandung Barat pada tahun 2015 berhasil menggugat Pembang-unan Apartemen Regitha Setiabudi dengan alasan pembangunan menimbulkan dampak ekologis (kekurangan air tanah/kesulitan air bersih).

Daribeberapakeberhasilangugatanyang disampaikan oleh kelompok kepentingan dan masyarakat, ada juga beberapa gugatan yang tidak berhasil menghentikan pembangunan properti mewah di Kawasan Bandung Utara. Gugatan kelompok kepentingan yang tidak berhasil tersebut tertulis pada daftar berikut : 1. Formas Bagus (Forum masyarakat Bangbayang dan Tubagus Ismail) menggugat Pembangunan Apartemen Jardinn Cihampelas pada tahun 2009, dengan alasan dampak sosial budaya (menghilangkan situs budaya pemandian Tjihampelas) dan dampak ekologis (hilangnya salah satu mata air) di kawasan tersebut. Gugatan ini tidak berhasil dan apartemen tersebut tetap berdiri.

2. Warga Kampung Ciosa dan warga desa Mekarsaluyu Kecamatan Cimenyan, Kabupaten Bandung pada tahun 2011 mengguggat Pembangunan Intercontinental Dago Resort and Hotel, dengan alasan Dampak Eko-logis (penimbunan 15 mata air,banjir dan longsor) dan dampak ekonomi bagi petani yang kehilangan mata pencaharian dan dampak sosial. Gugatan ini tidak berhasil menghentikan pembangunan resort dan hotel tersebut.

3. Asosiasi Warga Masyarakat Gunung Batu Kelurahan Sukaraja, Kecamatan Cicendo, Kota Bandung pada tahun 2012 menggugat Pembangunan Apartemen Gateway Pasteur, dengan alasan pembangunan tersebut menimbulkan dampak ekologis (kekurangan air tanah/ kesulitan air bersih, banjir dan Kemacetan). Gugatan ini tidak berhasil menghentikan pembangunan apartemen.

4. Warga masyarakat, dan Purnawirawan TNI Solihin GP, bersama DPKLTS, Walhi, AMBU, dan Bandung Heritage pada tahun 2012 menggugat Pembangunan Beverly Hill Residence dan Dago Suites Apartement, dengan alasan pengembang diduga menggunakan tanah Dinas Psikologi TNI AD dan menimbulkan dampak ekologis (longsor, kekeringan air, 
dan kemacetan). Gugatan ini tidak berhasil menghentikan pembangunan apartemen.

5. Warga masyarakat sekitar Ciumbeuleuit dan Walhi Jabar pada tahun 2014 menggugat pembangunan Parahyangan Residence Ciumbeuleuit, dengan alasan pembangunan apartemen tersebut menimbulkan polusi udara dan suara, serta ancaman intimidasi dari perusahaan terhadap warga. Gugatan ini tidak berhasil menghentikan pembangunan.

Berdasarkan data di atas, menunjukkan bahwasanya kelompok kepentingan sudah menjalankan perannya dalam mengawasi dan menyampaikan kritik terhadap kinerja pemerintahan. Namun demikian, meskipun per-lawanan demi perlawanan dilakukan, kelompok kepentingan tetap tidak kuasa membendung derasnya gempuran pembangunan di KBU. Meskipun jelas terdapat penyimpangan peraturan di KBU, namun hukum tidak bisa benar-benar ditegakkan. Penegakan hukum yang dilakukan tidak pernah memberikan efek jera kepada pelaku baik masyarakat dan swasta maupun aparatur yang melanggar kewenangan dengan memberikan ijin di KBU. Hal ini dinyatakan oleh informan ${ }^{8}$ bahwa :

"sulitnya penegakan hukum di KBU, karena hakim tata ruang tidak mengadop UU Tata Ruang. Padahal dalam UU tersebut, bagi pelanggar bisa diberikan hukuman pidana dan denda hingga miliaran rupiah. Baca ajalah di undang-undang tata ruangnya... menurut hakim tata ruang pelanggaran dengan hukuman berat apabila menimbulkan kematian, jadi pelanggaran KBU cuma dikenakan tipiring (tindak pidana ringan) jadi tidak ada efek jera"

Pernyataan diatas juga senada dengan pendapat informan ${ }^{9}$ yang menyatakan bahwa:

"Penegakan perda tidak bisa memberikan sanksi denda yang besar. Penegakan perda bagi pelanggar KBU hanya berupa sanksi pembongkaran. Jika tidak dibongkar solusinya pemilik bangunan hanya dikenakan tipiring berupa denda. Sayangnya untuk perda dendanya terlalu kecil, 5 jutaan. Bagi pengusaha hotel dan apartemen, denda ini tidak seberapa, tidak memberikan efek jera".

\footnotetext{
${ }^{8}$ Wawancara dengan ED, Bappeda Provinsi Jawa Barat, tanggal 18 Maret 2016

${ }^{9}$ Wawancara dengan BD, Dinas Pemukiman dan Perumahan Provinsi Jawa Barat, 14 Maret 2016
}

Masalah penegakan hukum perijinan pembangunan juga dikeluhkan oleh pemerintah kabupaten/kota. Kewenangan menjatuhkan sanksi pidana bagi pelanggaran hukum perijinan tersebut berada dibawah kekuasaan hakim di PTUN (Pengadilan Tinggi Tata Usaha Negara), namun keputusan hakim yang memberikan sanksi kepada pelanggar terlalu ringan, tidak pernah berdasarkan ketentuan peraturan perundang-undangan, sehingga tidak pernah menimbulkan efek jera ${ }^{10}$. Kelemahan penindakan hukum bagi pelanggar perijinan di Kawasan Bandung Utara ini setidaknya telah menjatuhkan wibawa pemerintah di mata masyarakat.

Berdasarkan hasil penelitian isu gugatan penyimpangan pembangunan $\mathrm{KBU}$, beberapa aktor yang terlibat dan saling berhadaphadapan, dimana pejabat pemerintah, aparat penegak hukum, elit politik, kelompok bisnis atau pemilik modal berhadap-hadapan dengan masyarakat biasa, kelompok kepentingan, dan kelompok media. Penerbitan ijin lokasi dan pendirian bangunan di KBU oleh pemerintah daerah bersifat mendapat kritik dari kelompok kepentingan karena tidak memperdulikan kepentingan masyarakat, bersifat pragmatis yang berpihak pada kelompok tertentu demi keuntungan jangka pendek yang pada akhirnya dapat mengakibatkan kerusakan lingkungan di KBU. Masalah penegakan hukum perijinan pembangunan juga dikeluhkan oleh pemerintah kabupaten/kota. Kewenangan menjatuhkan sanksi pidana bagi pelanggaran hukum perijinan tersebutberadadibawahkekuasaanhakimdiPTUN (Pengadilan Tinggi Tata Usaha Negara), namun keputusan hakim yang memberikan sanksi kepada pelanggar terlalu ringan, tidak pernah berdasarkan ketentuan peraturan perundangundangan, sehingga tidak pernah menimbulkan

\footnotetext{
${ }^{10}$ Masalah penegakan hukum tata ruang merupakan masalah yang sudah berlangsung lama, dalam sebuah ulasan media massa lokal Jawa Barat pernah diulas bahwa maraknya pelanggaran IMB dimulai dari kasus Hotel Planet (kini Vue Palace) di jalan Otista beberapa tahun lalu. Pada saat itu, pengembang hotel dinyatakan menang atas Pemerintah Kota Bandung dalam proses Pengadilan Tata Usaha Negara. Pengembang hotel secara nyata telah melanggar perda karena mendirikan bangunan melebihi ketentuan dalam IMB. Hotel tersebut diberi izin membangun empat lantai, tapi kenyataannya membangun hingga enam lantai. DI PTUN, Pemerintah Kota Bandung justru dikalahkan karena menurut pengadilan, lantai ima dan enam menjadi satu bagian yang tidak terpisahkan dari lantai pertama. Kasus Hotel Planet itu kemudian menjadi preseden buruk bagi Pemerintah Kota Bandung. Setelah kasus tersebut, berkembang pelanggaran-pelanggaran lainnya, termasuk yang terjadi di Kawasan Bandung Utara. Koran Gala Media, Perda dan Pergub tentang KBU Belum Efektif, Selasa, 20 April 2010
} 
efek jera ${ }^{11}$. Kelemahan penindakan hukum bagi pelanggar perijinan di Kawasan Bandung Utara ini setidaknya telah menjatuhkan wibawa pemerintah di mata masyarakat.

Strategi kelompok kepentingan dalam pengawasan pemanfaatan ruang di KBU masih belum cukup efektif dalam memberikan tekanan kepada pemerintah untuk merubah kebijakan dan mengawasi kinerja pemerintah dalam hal pemanfaatan ruang di KBU. Hal ini disebabkan karena rendahnya intensitas gerakan kelompok kepentingan dalam menyampaikan tuntutan. Tidak sedikit gerakan mereka meskipun diliput oleh media namun tidak didukung oleh jumlah massa yang besar. Bahkan diantara massa sendiri ada terpecah, ada yang mendukung dan ada juga yang kontra. Strategi gerakan yang dilakukan kelompok kepentingan sebagian besar hanya menyampaikan protes terhadap pemerintah dan elit politik (politisi di DPRD) dan mempublikasikan tuntutan melalui media massa. Meskipun lobby dan negosiasi kepada pemerintah dan elit politik sudah dilakukan namun belum cukup mengalahkan kepentingan pragmatis pejabat pemerintah dan kekuatan para pemilik modal. Hal ini menunjukkan adanya dominasi elit dan kelompok ekonomi atau pemilik modal yang berpengaruh terhadap kebijakan pembangun di KBU.

Hasil dari gerakan Kelompok kepentingan dalam pengawasan di KBU bagaimanapun menunjukkan bahwa kelompok kepentingan membutuhkan taktik atau strategi gerakan yang luar biasa untuk menekan pemerintah. Hal yang belum dilakukan kelompok kepentingan secara memadai adalah meraih dukungan masyarakat melalui pembentukan opini untuk membangun kesadaran masyarakat tentang bahayanya pembangunan terhadap dampak kerusakan lingkungan di KBU. Bagaimanapun,

\footnotetext{
${ }^{11}$ Masalah penegakan hukum tata ruang merupakan masalah yang sudah berlangsung lama, dalam sebuah ulasan media massa lokal Jawa Barat pernah diulas bahwa maraknya pelanggaran IMB dimulai dari kasus Hotel Planet (kini Vue Palace) di jalan Otista beberapa tahun lalu. Pada saat itu, pengembang hotel dinyatakan menang atas Pemerintah Kota Bandung dalam proses Pengadilan Tata Usaha Negara. Pengembang hotel secara nyata telah melanggar perda karena mendirikan bangunan melebihi ketentuan dalam IMB. Hotel tersebut diberi izin membangun empat lantai, tapi kenyataannya membangun hingga enam lantai. DI PTUN, Pemerintah Kota Bandung justru dikalahkan karena menurut pengadilan, lantai ima dan enam menjadi satu bagian yang tidak terpisahkan dari lantai pertama. Kasus Hotel Planet itu kemudian menjadi preseden buruk bagi Pemerintah Kota Bandung. Setelah kasus tersebut, berkembang pelanggaran-pelanggaran lainnya, termasuk yang terjadi di Kawasan Bandung Utara. Koran Gala Media, Perda dan Pergub tentang KBU Belum Efektif, Selasa, 20 April 2010
}

dukungan massa yang besar, -sebagaimana yang dikemukakan oleh Duverger- merupakan sumberkekuatangerakan kelompok kepentingan dalam melakukan tekanan sehingga memaksa pemerintah untuk memenuhi tuntutan dari kelompok kepentingan (Duverger, 1984: 137). Pembentukan opini ini akan lebih efektif apabila didukung oleh bantuan media massa dalam mensosialisasikan opini yang dibangun. Dalam pembentukan opini dan membangun kesadaran kolektif masyarakat tentu saja kelompok kepentingan perlu menyatakan argumen yang kuat sehingga isu yang dikemukakan diterima secara rasional oleh masyarakat.

\section{SIMPULAN}

Maraknya pembangunan di Kawasan Bandung Utara (KBU) menunjukkan kondisi yang mengkhawatirkan. Koefisien Wilayah Terbangun sudah mencapai lebih dari $70 \%$ yang berdampak pada kerusakan lingkungan, ekologis dan memberikan dampak sosial ekonomi bagi masyarakat di wilayah KBU. Padahal KBU sudah ditetapkan sebagai kawasan konservasi yang memberikan perlindungan ekologis dan kebutuhan air bagi wilayah dibawahnya (Bandung Raya dan sekitarnya). Kondisi kerusakan di KBU ini memanggil kepedulian para masyarakat yang aktif dalam kelompok-kelompok kepentingan untukmemperjuangkan kepentingan masyarakat dan melestarikan lingkungan KBU. Perlawanan kelompok-kelompok kepentingan tersebut harus berhadap-hadapan dengan aparat/pejabat pemerintah, elit politik, penegak hukum, dan pemilik modal. Meskipun penolakan kelompok-kelompok kepentingan terhadap pembangunan di KBU sudah cukup intensif, namun tidak juga berhasil meredam gencarnya pembangunan di kawasan tersebut, terutama minat para investor untuk membangun gedung-gedung tinggi (high rise building) seperti hotel-hotel dan apartemen. Meskipun pembangunan di KBU secara jelas melanggar peraturan daerah Nomor 1 Tahun 2008, dimana setiap ijin membangun (IMB) yang dikeluarkan kabupaten/kota harus memiliki rekomendasi gubernur, namun penyimpanganpenyimpangan perijinan sebagai kolusi aparatur pemerintah dan pemilik modal terus berlangsung. Ketidakmampuan kelompok kepentingan dalam meredam pesatnya pembangunan menunjukkan strategi kelompok kepentingan belum efektif untuk menekan pemerintah menghentikan 
pemberian ijin dan mencegah pembangunan di KBU yang dilakukan oleh para pemilik modal. Bagaimanapun, gerakan kelompok kepentingan perlu meraih dukungan masyarakat melalui pembentukan opini dengan cara membangun kesadaran masyarakat tentang bahayanya pembangunan terhadapdampakkerusakanlingkungan di KBU. Pembentukan opini ini dirasa akan lebih efektif apabila upaya ini didukung oleh bantuan media massa dalam mensosialisasikan opini tersebut.

\section{DAFTAR PUSTAKA}

Duverger, Maurice. 1984. Partai Politik dan Kelompok-Kelompok Penekan. Jakarta: Bina Aksara

Gaffar, Affan. 1999. Politik Indonesia: Transisi Menuju Demokrasi, Yogyakarta: Pustaka Pelajar

Mas'oed, Mochtar dan Collin MacAndrews. 1995. Perbandingan Sistem Politik. Yogyakarta: Gadjah Mada University Press
Surbakti, Ramlan. 1992. Memahami Ilmu Politik. Jakarta: Gramedia Widiasarana Indonesia

Gala Media, "Perda dan Pergub tentang KBU Belum Efektif", "Gala Media", Selasa, 20 April 2010

Republika, "Kasus Bandung Utara Resahkan Investor dan Konsumen”, Republika, Selasa 24 Januari 1995

Suara Pembaharuan, "Audit Bangunan di Kawasan Bandung Utara", Suara Pembaharuan, 9 Desember 2013

BPK RI. 2007. http:/www.bpk.go.id/doc/ hapsem/2007ii/APBD/273_Kota Bandung_Perc_Lingk_udara.PDF, diakses pada tanggal 25 Januari 2016

Kompas Online. Warga Malaysia dan Singapura TertarikApartemen Bandung, 23 September 2015, www.kompas.com diakses tanggal 4 Juni 2016

$\mathrm{h} \mathrm{t} \mathrm{t} \mathrm{p} \mathrm{s} \mathrm{:} \mathrm{/} \mathrm{/} \mathrm{m.te} \mathrm{m} \mathrm{p} \mathrm{o.co/} \mathrm{r} \mathrm{e} \mathrm{a} \mathrm{d} \mathrm{/}$ news/2014/08/20/058601022/penertibanbangunan-liar-di-bandung-utara-mandek, diakses tanggal 16 Juli 2016 